\title{
Bladder cancer and human papillomavirus association: a systematic review and meta-analysis
}

\author{
Alireza Khatami* ${ }^{*}$, Zahra Salavatiha and Mohammad Hossein Razizadeh
}

\begin{abstract}
Background: The possible association of human papillomavirus (HPV) and bladder cancer has been controversial. Older findings suggest a significant association between the virus and bladder cancer. The aim of this study was to evaluate the data from the last ten years to estimate the prevalence of the virus in bladder cancer patients and to assess the association between the virus and cancer.

Method: A search of major databases was conducted to retrieve published English language studies between January 2011 and March 2021. In the present study overall prevalence of the virus in bladder cancer patients was estimated along with the prevalence of subgroups. Also, the possible associations between the prevalence of the virus and bladder cancer and the possible impact of variables in the geographical area and the type of sample were measured by comprehensive meta-analysis software (V2.2, BIOSTAT).
\end{abstract}

Results: Unlike previous studies, despite the relatively high prevalence of the virus [pooled prevalence: $14.3 \%(95 \% \mathrm{Cl}$ 8.9-22.2\%)] no significant association was found between HPV and bladder cancer (OR 2.077, 95\% Cl 0.940-4.587). No significant association was found between geographical area (except Asia) and type of sample with bladder cancer.

Conclusions: Given the significant prevalence, despite the insignificance of the association between virus and cancer, it seems that more studies with case-control design are needed to elucidate this association.

Keywords: Human papillomavirus, HPV, Bladder cancer, Meta-analysis

\section{Introduction}

Bladder cancer is the tenth most common cancer globally, with 573,000 new cases and 213,000 deaths each year [1]. It is about four times more common in men than women, and it is the sixth most common cancer and the ninth leading cause of cancer death in men [2]. The well-known risk factors for bladder cancer include cigarette smoking, several occupations with exposures to aromatic amines (e.g. industrial dye manufacturing), the drug cyclophosphamide, and high use of the analgesic

*Correspondence: AKH.Alirezakhatami@gmail.com Department of Virology, Faculty of Medicine, Iran University of Medical Sciences, Tehran, Iran phenacetin [3]. There is an association between infection with parasitic agents (Schistosomiasis) and bacterial agents (Non-specific urinary tract infections Gonorrhea) with viral infections such as the Human papillomavirus (HPV), Human immunodeficiency virus, Bovine leukemia virus, BK virus, Herpes simplex virus [3-5]. Studies indicated that viruses cause $15-20 \%$ of all human cancers, of which about 10 percent are caused by HPV [6]. HPV is regarded as the most common viral sexually transmitted infection worldwide; more than 200 types of papillomavirus have been identified, which 14 types of them are regarded as the high-risk (HR) types, including $16,18,31,33,35,39,45,51,52,56,58,59,68$, and 73 and have been observed in $90 \%$ of papillomavirus cancers [7-10]. HPVs are involved in the development of cervical, original author(s) and the source, provide a link to the Creative Commons licence, and indicate if changes were made. The images or other third party material in this article are included in the article's Creative Commons licence, unless indicated otherwise in a credit line to the material. If material is not included in the article's Creative Commons licence and your intended use is not permitted by statutory regulation or exceeds the permitted use, you will need to obtain permission directly from the copyright holder. To view a copy of this licence, visit http://creativecommons.org/licenses/by/4.0/. The Creative Commons Public Domain Dedication waiver (http://creativecommons.org/publicdomain/zero/1.0/) applies to the data made available in this article, unless otherwise stated in a credit line to the data. 
vagina, vulvar cancer in females, penile cancer in males, and anal cancers in both genders [11]. Due to the proximity of the genital tract and urinary tract, the risk of urinary tract infection with HPV is high [12]. Although various meta-analysis studies have been performed in different years on the possible role of HPV in the development of bladder cancer, the role of this virus in the development of bladder cancer is still controversial.

The present meta-analysis study reviewed articles over 10 years ago about the potential association of HPV in bladder cancer, besides the latest global prevalence of the virus in bladder cancer patients, also in this study, we discuss about the effects of various factors, including geographical distribution and type of sample used for virus detection.

\section{Methods}

\section{Systematic search strategy}

This study was conducted based on the PRISMA (Preferred Reporting Items for Systematic Reviews and MetaAnalyses) protocols. Main electronic databases include Medline (PubMed), Scopus, Web of Science, and Google Scholar were systematically searched by two investigators independently (A.K. and M.R.) for related articles published from January 2011 to March 2021. The used search keywords and terms were "HPV or human papillomavirus" AND "bladder cancer". Additionally, the references of all original and review articles were hand-searched to finding other relevant studies.

\section{Including and excluding criteria}

Eligible studies were analyzed by abstract and title. First, all the articles were imported into the Endnotes software, and in the next step, duplicated articles were then removed. The following inclusion criteria were applied for recruited publications in this study: (1) articles with case-control, cross-sectional, and cohort design; (2) published studies in the English language; (3) the papers with full-text, and (4) papers published from January 2011 to March 2021 with a digital object identifier (DOI); In addition, we also excluded studies with the following reasons: (1) Research on animals and in vitro; (2) all types of review papers, letters, comments, case reports, and case series.

\section{Data extraction}

Data from all retrieved studies were extracted by two authors and double checked. If there were any discrepancies of opinion or disagreement between the two investigators, they would reach a consensus by consensus and discussion with the lead investigator (A.K.). We extracted the following variables from articles: first author's last name, year of publication, country, total numbers of cases and controls, diagnosis methods, and type of sample.

\section{Quality assessment}

We used the Joanna Briggs Institute (JBI) checklist for the quality assessment of the included articles [13], which contains ten questions with four answering options including, Yes, No, Unclear, and Not applicable; the overall score of each study can be a number between 1 and 10 . Scores of 7-10 were considered high quality, and 4 to 6 were considered moderate quality for the studies. Therefore, we have decided to include and exclude the studies with 4 to 10 scores and $\leq 3$ points, respectively.

\section{Data synthesis and statistical analysis}

In the present systematic review and meta-analysis, we estimated the pooled odd ratio and prevalence of HPV in bladder cancer patients based on the random effect model (REM) with a 95\% confidence interval (CI). The REM application lets for a distribution of true effect sizes between studies. Prevalence was also estimated based on subgroups of geographical area (continents), diagnostic method, cancer grade, sample type, virus genotype, HPV type (high risk and low risk), and gender of the subjects. In addition to the overall odd ratio, the geographic area and type of samples with bladder cancer association were calculated. The I2 statistic was performed to evaluate the studies' heterogeneity, and the publication bias was assessed by Egger's regression test, and p-value $<0.05$ was considered statistically significant; funnel plot represents the publication bias between studies. We applied the comprehensive meta-analysis software (version 2, Biostat, USA) for all analytical steps.

\section{Results}

\section{Literature search}

In the initial literature search strategy, a total of 1326 studies were identified from international electronic databases. In addition, 3 relevant papers were identified when searching for reference lists manually. Altogether, 659 duplicate studies were excluded, after the screening of 670 articles by title and abstract, which resulted in the removal of 620 articles. The remaining 51 articles were assessed for eligibility by the full-text review. After screening the full texts of the included articles, 24 studies were excluded based on reasons described in Fig. 1, and finally, 26 articles (27 datasets) were included in the meta-analysis (Fig. 2).

\section{Study characteristics}

Twenty-seven datasets with a total of 2954 bladder cancer patients from eighteen countries were included in this study. The publication date of the studies was from 


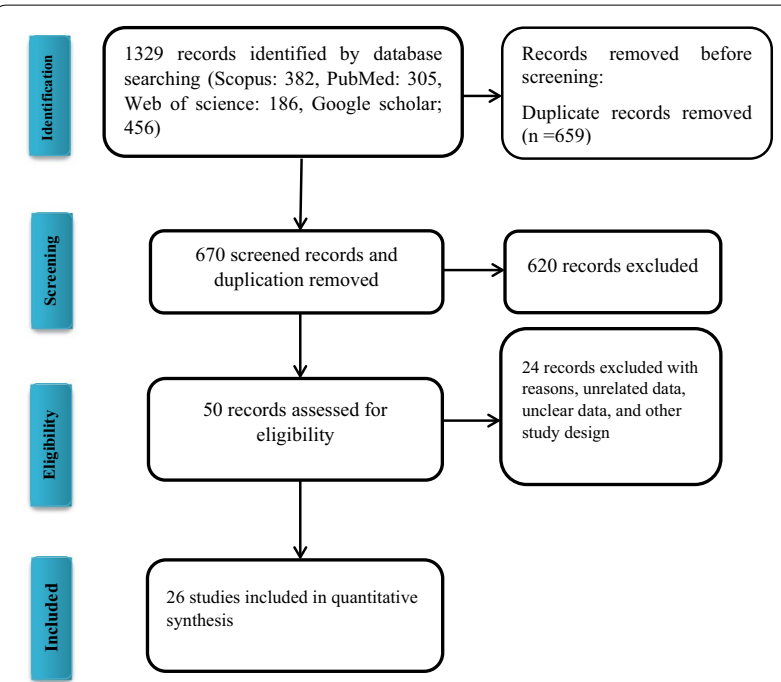

Fig. 1 Flow diagram of the search strategy and studies selection process for studies in meta-analysis

January 2011 to March 2021. Twenty-seven records were selected for further analysis, of which 11 were from Asia, 1 study from Oceania, 4 studies from America, 3 studies from Europe, and 1 study from Africa. The characteristics of the selected studies of this analysis are summarized in Table 1.

\section{Pooled prevalence of HPV in the bladder cancer patients}

The total number of bladder cancer patients included in this meta-analysis was 2954 from adults based on the results of 27 datasets. The pooled prevalence of HPV infection among bladder cancer patients was 14.3\% (95\% CI 8.9-22.2\%) based on a random-effects metaanalysis. In sub-group analysis by continent, the maximum and minimum prevalence of HPV infection among bladder cancer patients were found in Africa and Oceania, respectively $(51.2,95 \%$ CI $36.6-65.6 \%$ vs. 2.2 , $95 \%$ CI $0.8-5.6 \%)$. Sub-group analysis based on HPV types showed that high-risk types had the highest prevalence (16.2\%, 95\% CI 9.8-25.5\%), while low-risk types showed a lower prevalence (4.8\%, 95\% CI 2.2-10.2\%). Details of the Pooled prevalence of HPV and bladder cancer risk for the subgroups are presented in Table 2.

\section{The association of HPV with bladder cancer}

In 12 studies, the meta-analysis showed that HPV was not associated with bladder cancer, as shown in Fig. 3 [OR $2.077(0.940-4.587)]$. However, according to the subgroup analysis, the highest association between HPV and the risk of bladder cancer was in Asia $(\mathrm{OR}=6.289$; 95\% CI 2.167-18.250). Details of the association between
HPV and bladder cancer risk for the subgroups are presented in Table 3.

\section{Publication bias}

Egger's regression test results for publication bias calculation showed the statistically significant $(P<0.000)$, this can be due to the low number of studies and/or studied subjects, the very high and/or low number of positive cases in some studies, the difference between diagnostic methods and the difference between operators skills (Fig. 4). The results of $I^{2}$ statistics revealed significant heterogeneity among the included studies $(\mathrm{df}=26, \mathrm{P}<0.000$, $\mathrm{I}^{2}=93.864 \%$ ).

\section{Discussion}

Bladder cancer is the tenth most common cancer in the world, with high morbidity and mortality rate. In addition to factors involved in cancer progressions such as gender, genetics, cigarette smoking, and exposure to polycyclic aromatic compounds, viral infections such as the human papilloma virus (HPV) have been introduced to be effective in the bladder cancer etiology and/ or development [3]. The association between HPV and bladder cancer has been controversial, according to previous meta-analysis studies. However, with the relative increase in studies in this field and the comparatively suitable sample size for assessing the prevalence and association of HPV and bladder cancer, the present study addresses this relationship with more up-to-date information. Despite the latest meta-analysis results, our findings did not show a statistically significant association between HPV infection and bladder cancer [OR 2.077 (95\% CI 0.940-4.587)]. The geographical spread of the virus and association with bladder cancer as well as the applied viral infections diagnostic samples and technique has always been interesting and obscure; in the last decade, the used diagnostic methods were mostly molecular, and the included studies for the present meta-analysis were also mostly molecular-based. The highest prevalence was according to the PCR method (36.7\%, 95\% CI $33.4-40.1 \%$ ); this is probably due to the high number of studies performed with this technique and also the high sensitivity and specificity of this technique in viral diagnosis. Also, it seems that geographical distribution has an impact on the association between HPV and bladder cancer. Giving to the subgroup analysis by geographical area, unlike other areas, there was a significant relationship in Asia (OR 6.289, 95\% CI 2.167-18.250); according to the study by Li et al., which is in line with our findings, this association could be related to genetics, ethnic, lifestyle, and even sexual behaviors as well as other unknown risk factors. However, it should be noted that the lack of association in other regions, especially Africa, is probably 
Study name

Alexander et al. (2014)
Borkowska et al. (2014)
Chapman-Fredricks et al. (2013)
Chapman-Fredricks et al. (2013)
Collins et al. (2020)
Golovina et al. (2014)
Golovina et al. (2016)
Gordetsky et al. (2020)
Javanmard et al. (2019)
Jorgensena et al. (2018)
Llewellyn et al. (2018)
Moghadam et al. (2020)
Shigehara et al. (2013)
Yan et al. (2020)
Pichler et al. (2015)
Barghi et al. (2012)
uttam et al. (2018)
Abdollahzadeh et al. (2018)
Yildizhan et al. (2020)
Sorlozanoa et al. (2011)
Schmid et al. (2015)
Sarier et al. (2019)
Panagiotakis et al. (2012)
Polese et al. (2011)
Kim et al. (2014)
Cai et al. (2011)
Anwar et al. (2015)
Berrada et al.. (2013)
Pooled prevalence

\section{Statistics for each study}

Event Lower Upper

rate limit limit

$\begin{array}{lll}0.014 & 0.001 & 0.182\end{array}$

$\begin{array}{lll}0.135 & 0.081 & 0.215\end{array}$

$\begin{array}{llll}0.033 & 0.002 & 0.366\end{array}$

$\begin{array}{llll}0.214 & 0.071 & 0.494\end{array}$

$\begin{array}{llll}0.015 & 0.001 & 0.196\end{array}$

$\begin{array}{llll}0.457 & 0.302 & 0.621\end{array}$

$\begin{array}{llll}0.376 & 0.287 & 0.474\end{array}$

$\begin{array}{lll}0.005 & 0.001 & 0.033\end{array}$

$\begin{array}{llll}0.809 & 0.725 & 0.872\end{array}$

$\begin{array}{lll}0.120 & 0.069 & 0.200\end{array}$

$\begin{array}{llll}0.001 & 0.000 & 0.010\end{array}$

$\begin{array}{llll}0.226 & 0.157 & 0.316\end{array}$

$\begin{array}{llll}0.060 & 0.025 & 0.135\end{array}$

$\begin{array}{lll}0.288 & 0.220 & 0.366\end{array}$

$\begin{array}{llll}0.022 & 0.008 & 0.056\end{array}$

$\begin{array}{lll}0.293 & 0.205 & 0.400\end{array}$

$\begin{array}{llll}0.010 & 0.001 & 0.138\end{array}$

$\begin{array}{lll}0.224 & 0.140 & 0.339\end{array}$

$\begin{array}{llll}0.035 & 0.013 & 0.091\end{array}$

$\begin{array}{lll}0.094 & 0.048 & 0.177\end{array}$

$\begin{array}{llll}0.005 & 0.000 & 0.068\end{array}$

$\begin{array}{lll}0.290 & 0.195 & 0.407\end{array}$

$\begin{array}{llll}0.016 & 0.001 & 0.211\end{array}$

$\begin{array}{lll}0.711 & 0.621 & 0.786\end{array}$

$\begin{array}{llll}0.171 & 0.079 & 0.333\end{array}$

$\begin{array}{lll}0.654 & 0.542 & 0.751\end{array}$

$\begin{array}{lll}0.140 & 0.088 & 0.217\end{array}$

$\begin{array}{lll}0.512 & 0.366 & 0.656\end{array}$

$\begin{array}{lll}0.143 & 0.089 & 0.222\end{array}$

\section{Event rate and $95 \% \mathrm{Cl}$}

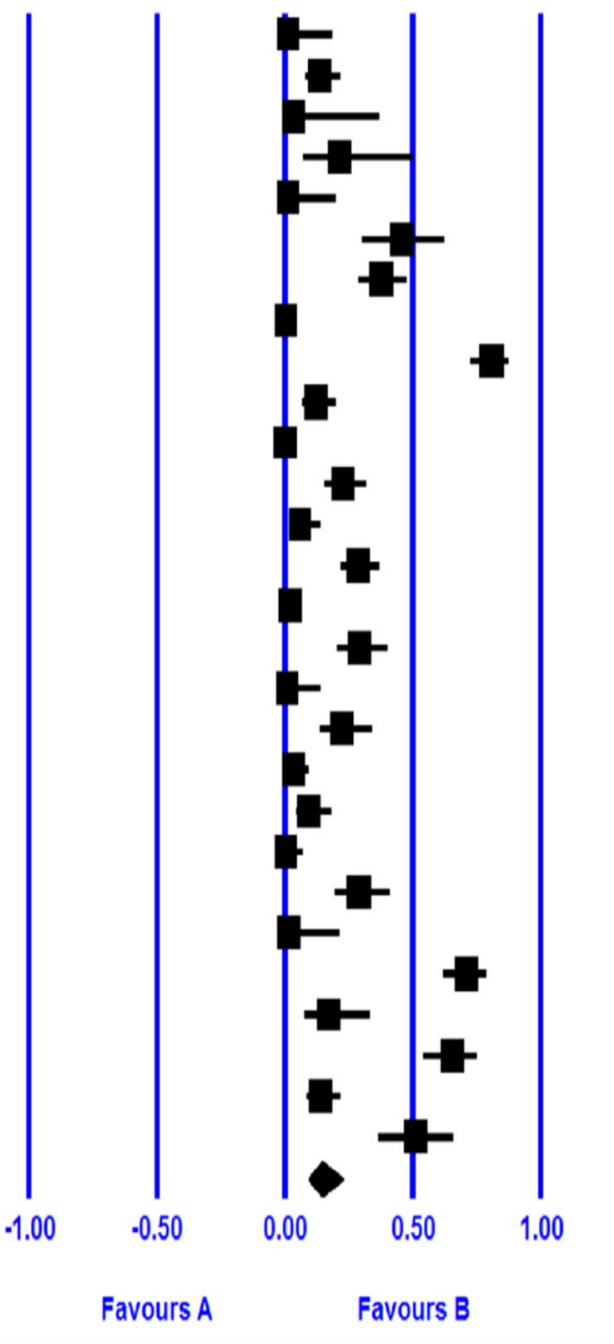

Fig. 2 Forest plot of the pooled prevalence for HPV in bladder cancer

due to the small number of studies and the sample size. Up to now, the possible association of the virus in bladder cancer according to the diagnostic method has been discussed, but not about the sample taken for diagnosis. We analyzed the type of sample used to detect the virus in bladder cancer patients. The results showed no statistically significant relationship between the either frozen and/or FFPE sample type and detection of bladder cancer. Among the possible related factors, gender is controversial Most studies indicated that bladder cancer is more common in men than women [41, 42], but some studies showed that SCC of bladder cancer is more common in women than men $[20,30]$. The results of our study showed a higher risk of bladder cancer in men than women $(19.7 \%$, 95\% CI $12.9-28.8 \%$ versus $15.7 \%$ 95\% CI $8.1-28.3 \%)$, which is in line with the study by Moghadam et al. [6].

Several studies have surveyed the prevalence of highrisk and low-risk types of virus and their involvement in the development of bladder cancer [17, 18, 43-45]. Based on our findings, the prevalence of high-risk types was higher $(16.2 \%$, 95\% CI $9.8-25.5 \%$ versus $4.8 \%$, 95\% CI 2.2-10.2\%), and in the case of high-risk genotypes, the prevalence of HPV 18 was not significantly different from 


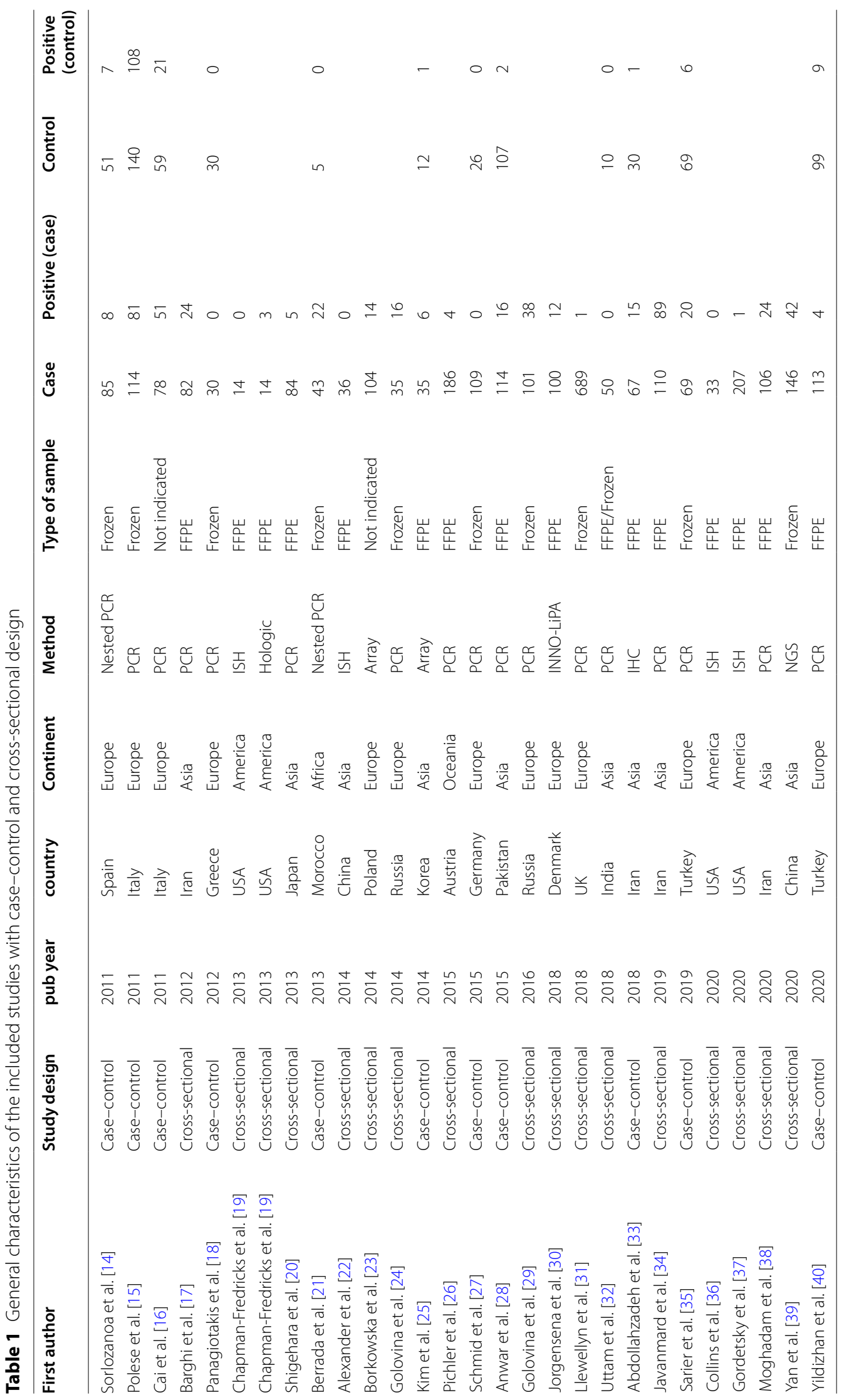


Table 2 Overall prevalence and subgroup analysis results

\begin{tabular}{|c|c|c|c|c|c|c|}
\hline \multirow[t]{2}{*}{ Characteristics } & \multirow[t]{2}{*}{ Categories } & \multirow[t]{2}{*}{ No. of data sets } & \multirow{2}{*}{$\begin{array}{l}\text { Pooled prevalence }(\%) \\
(95 \% \mathrm{Cl})\end{array}$} & \multicolumn{3}{|c|}{ Heterogeneity } \\
\hline & & & & Q value & P-value & $I^{2} \%$ \\
\hline Overall & - & 28 & $14.3(8.9-22.2)$ & 440.035 & 0.000 & 93.864 \\
\hline \multirow[t]{5}{*}{ Continent } & Africa & 1 & $51.2(36.6-65.6)$ & 0.000 & 1.000 & 0.000 \\
\hline & America & 5 & $3.1(0.4-21.9)$ & 12.795 & 0.005 & 76.553 \\
\hline & Asia & 17 & $19.6(10.1-34.7)$ & 139.213 & 0.000 & 93.535 \\
\hline & Europe & 3 & $14.9(6.9-29.4)$ & 223.190 & 0.000 & 95.071 \\
\hline & Oceania & 8 & $2.2(0.8-5.6)$ & 0.000 & 1.000 & 0.000 \\
\hline \multirow[t]{2}{*}{ Sample } & FFPE & 15 & $10.6(51.1-21.0)$ & 216.691 & 0.000 & 93.539 \\
\hline & Frozen & 10 & $20.4(10.5-35.9)$ & 134.367 & 0.000 & 93.302 \\
\hline \multirow[t]{3}{*}{ Method } & Array & 2 & $14.5(9.5-21.4)$ & 0.287 & 0.592 & 0.000 \\
\hline & ISH & 4 & $1.1(0.3-3.7)$ & 1.367 & 0.713 & 0.000 \\
\hline & $P C R$ & 18 & $36.7(33.4-40.1)$ & 357.885 & 0.000 & 95.250 \\
\hline \multirow[t]{2}{*}{ Grade } & High & 5 & $29.4(19.0-42.6)$ & 16.551 & 0.002 & 75.833 \\
\hline & Low & 5 & $22.4(13.1-35.5)$ & 10.682 & 0.030 & 62.553 \\
\hline \multirow[t]{2}{*}{ Genotype } & HPV18 & 6 & $10.0(4.9-19.2)$ & 42.449 & 0.000 & 88.221 \\
\hline & HPV16 & 14 & $10.2(5.4-18.5)$ & 159.128 & 0.000 & 91.830 \\
\hline \multirow[t]{2}{*}{ HPV type } & High-risk & 16 & $16.2(9.8-25.5)$ & 213.652 & 0.000 & 92.979 \\
\hline & Low-risk & 5 & $4.8(2.2-10.2)$ & 12.515 & 0.014 & 68.039 \\
\hline \multirow[t]{2}{*}{ Gender } & Male & 10 & 19.7 (12.9-28.8) & 58.620 & 0.000 & 84.647 \\
\hline & Female & 9 & $15.7(8.1-28.3)$ & 21.520 & 0.006 & 62.825 \\
\hline
\end{tabular}

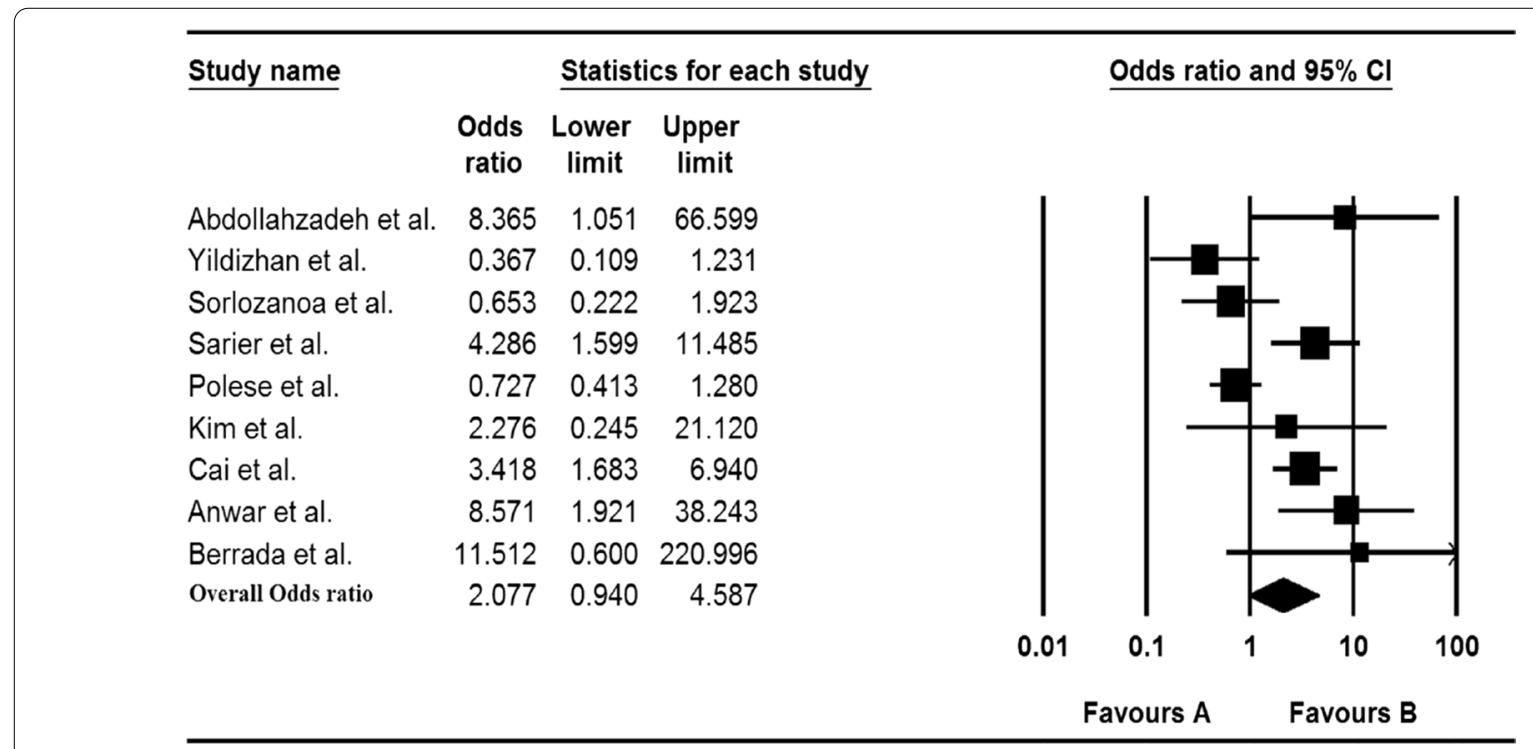

Fig. 3 Forest plot of the overall odds ratio for association of HPV and bladder cancer

that of HPV 16 (10.0\%, 95\% CI 4.9-19.2\% versus $10.2 \%$, 95\% CI 5.4-18.5\%).

However, we could not found any significant association between bladder cancer and HPV in our study; the results of our study are in line with various studies conducted by different groups in which no significant association was found between HPV infection and bladder cancer [14, 15, 18, 27, 28, 37, 45-52] In contrast, previous Meta-analyzes emphasized the significant association between virus and bladder cancer [44]. By analyzing newer studies, our results were inconsistent with previous Meta-analyzes; also, some studies have been 
Table 3 Overall odd ratio and sub group analysis for case-control studies results

\begin{tabular}{lllcr}
\hline Characteristics & Categories & No. of data sets & Pooled OR (\%) (95\% Cl) & $\begin{array}{l}\text { Heterogeneity } \\
\mathbf{I}^{2} \%\end{array}$ \\
\hline Overall & & & & 75.839 \\
Continent & - & 12 & $2.077(0.940-4.587)$ & 0.000 \\
& Africa & 1 & $11.512(0.600-220.996)$ & 0.000 \\
& Asia & 4 & $6.289(2.167-18.250)$ & 82.292 \\
Sample & Europe & 7 & $1.125(0.503-3.113)$ & 76.856 \\
& FFPE & 4 & $2.584(0.447-14.948)$ & 76.355 \\
\hline
\end{tabular}

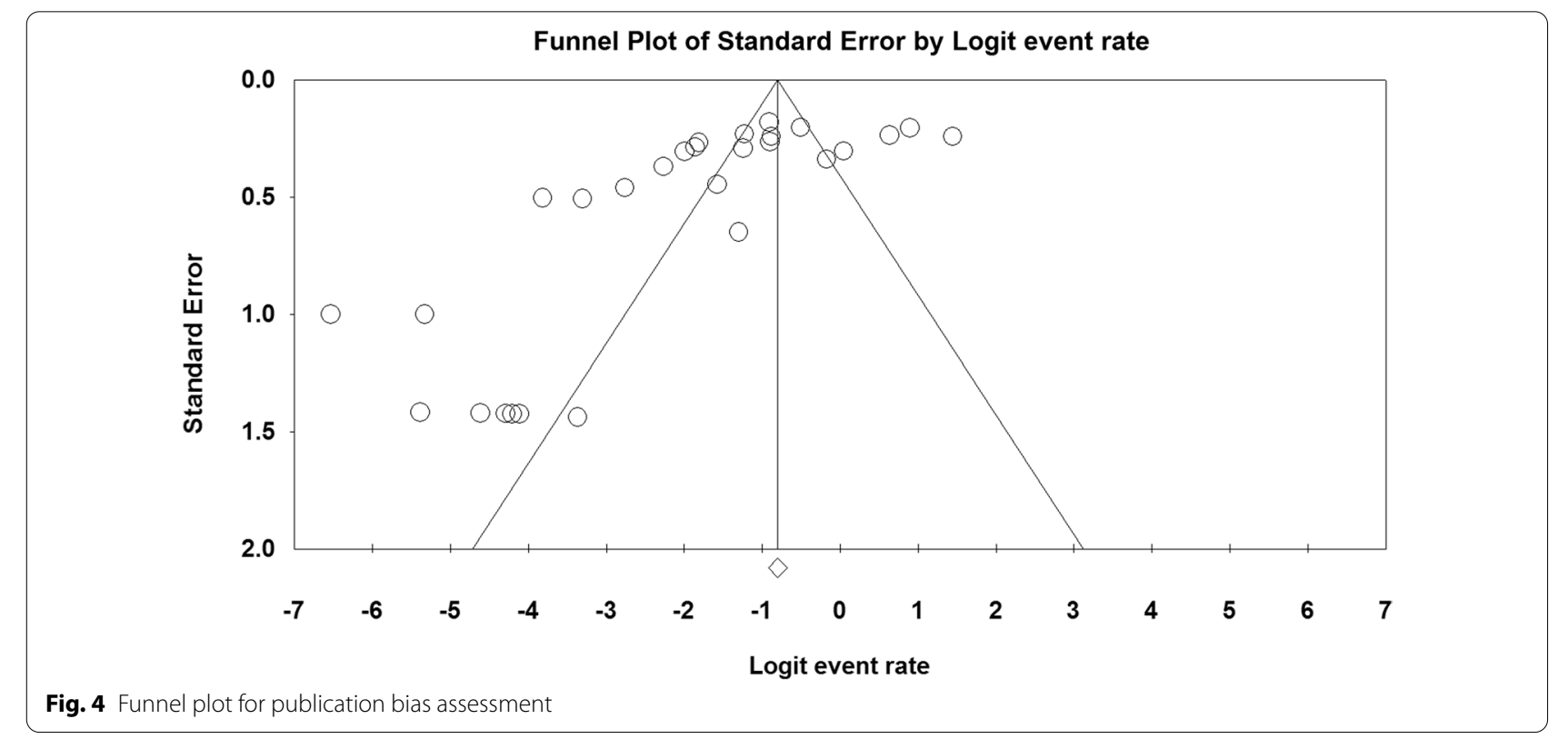

failed to prove the association between HPV and SCC of bladder cancer and refuse the causative role of this virus [48, 53-55]. It also appears that HPV may be involved in the progression of different stages of bladder cancer due to the inactivation of tumor suppressors and a number of unknown mechanisms. The analysis results showed a high prevalence of the virus in the high grade of bladder cancer (Table 2).

The present study has faced limitations, such as the geographical limitations of the reports, so that reports were not available from some countries and continents according to the inclusion criteria. Other limitations included studies published in local languages.

\section{Conclusions}

Despite the results of previous meta-analysis studies that reported the etiological role of HPV in bladder cancer, we conclude there is no significant association between HPV infection and bladder cancer. However, according to the analysis of studies of the last ten years, a relatively high prevalence of the virus was observed, which raises the possibility that with the increase of studies in this field, more comprehensive results will be obtained. Furthermore, the geographical area has a potential impact on the association between HPV and bladder cancer as a high prevalence of HPV infection was observed in Asia.

\section{Acknowledgements \\ None.}

Authors' contributions

The study was designed by MR and AK and. ZS and MR collaborated in the studies search, data extraction, and AK helped in double checking. MR and AK collaborated in the manuscript writing and ZS helped in revision. All the authors commented on the drafts of the manuscript and approved the final version of the article. All authors read and approved the final manuscript.

\section{Funding}

This research received no specific grant from any funding agency, commercial or not-for-profit sectors.

Availability of data and materials

All needed data are available in manuscript. 


\section{Declarations}

Ethics approval and consent to participate

Not applicable.

\section{Consent for publication}

Not applicable.

\section{Competing of interest}

None.

Received: 24 June 2021 Accepted: 10 January 2022

Published online: 21 January 2022

\section{References}

1. Ferlay J, Colombet M, Soerjomataram I, Parkin DM, Piñeros M, Znaor A, et al. Cancer statistics for the year 2020: An overview. Int J Cancer. 2021;6:66.

2. Kamat AM, Hahn NM, Efstathiou JA, Lerner SP, Malmström P-U, Choi W, et al. Bladder cancer. The Lancet. 2016:388(10061):2796-810.

3. Abol-Enein $\mathrm{H}$. Infection: is it a cause of bladder cancer? Scand J Urol Nephrol. 2008;42(sup218):79-84.

4. Khatami A, Bahadory S, Ghorbani S, Saadati H, Zarei M, Soleimani A, et al. Two rivals or colleagues in the liver? Hepatit B virus and Schistosoma mansoni co-infections: a systematic review and meta-analysis. Microb Pathogenesis. 2021;66:104828

5. Khatami A, Pormohammad A, Farzi R, Saadati H, Mehrabi M, Kiani SJ, et al. Bovine leukemia virus (BLV) and risk of breast cancer: a systematic review and meta-analysis of case-control studies. Infectious Agents Cancer. 2020;15(1):1-8

6. Moghadam SO, Mansori K, Nowroozi MR, Afshar D, Abbasi B, Nowroozi A. Association of human papilloma virus (HPV) infection with oncological outcomes in urothelial bladder cancer. Infect Agents Cancer. 2020;15(1):1-8.

7. Bouvard V, Baan R, Straif K, Grosse Y, Secretan B, El Ghissassi F, et al. A review of human carcinogens-Part B: biological agents. Lancet Oncol. 2009;10(4):321-2

8. Cogliano V, Baan R, Straif K, Grosse Y, Secretan B, El Ghissassi F. Carcinogenicity of human papillomaviruses. Lancet Oncol. 2005;6(4):204.

9. Doorbar J, Quint W, Banks L, Bravo IG, Stoler M, Broker TR, et al. The biology and life-cycle of human papillomaviruses. Vaccine. 2012;30:F55-70.

10. Muñoz N, Bosch FX, De Sanjosé S, Herrero R, Castellsagué X, Shah KV, et al. Epidemiologic classification of human papillomavirus types associated with cervical cancer. N Engl J Med. 2003;348(6):518-27.

11. Kjær SK, Frederiksen K, Munk C, Iftner T. Long-term absolute risk of cervical intraepithelial neoplasia grade 3 or worse following human papillomavirus infection: role of persistence. J Natl Cancer Inst. 2010;102(19):1478-88.

12. Pathak N, Dodds J, Zamora J, Khan K. Accuracy of urinary human papillomavirus testing for presence of cervical HPV: systematic review and meta-analysis. BMJ. 2014:66:349.

13. Munn Z, Aromataris E, Tufanaru C, Stern C, Porritt K, Farrow J, et al. The development of software to support multiple systematic review types: the Joanna Briggs Institute System for the Unified Management, Assess ment and Review of Information (JBI SUMARI). Int J Evid Based Healthc. 2019;17(1):36-43.

14. Sorlózano A, Moraga Al, Pareja M, Villegas E, Villahermosa ML, Carrillo JA, et al. Detection and genotyping by microarray of human papillomavirus in tissue of bladder and bladder carcinoma biopsy.

15. Polesel J, Gheit T, Talamini R, Shahzad N, Lenardon O, Sylla B, et al. Urinary human polyomavirus and papillomavirus infection and bladder cancer risk. Br J Cancer. 2012:106(1):222-6.

16. Cai T, Mazzoli S, Meacci F, Nesi G, Geppetti P, Malossini G, et al. Human papillomavirus and non-muscle invasive urothelial bladder cancer: potential relationship from a pilot study. Oncol Rep. 2011;25(2):485-9.

17. Barghi MR, Rahjoo T, Borghei M, Hosseini-Moghaddam SM, Amani D, Farrokhi B. Association between the evidence of human papilloma virus infection in bladder transitional cell carcinoma in men and cervical dysplasia in their spouses. Arch Iran Med. 2012;15(9):66.

18. Panagiotakis Gl, Papadogianni D, Chatziioannou MN, Lasithiotaki I, Delakas D, Spandidos DA. Association of human herpes, papilloma and polyoma virus families with bladder cancer. Tumor Biol. 2013:34(1):71-9.

19. Chapman-Fredricks JR, Cioffi-Lavina M, Accola MA, Rehrauer WM, GarciaBuitrago MT, Gomez-Fernandez C, et al. High-risk human papillomavirus DNA detected in primary squamous cell carcinoma of urinary bladder. Arch Pathol Lab Med. 2013;137(8):1088-93.

20. Shigehara K, Kawaguchi S, Sasagawa T, Nakashima K, Nakashima T, Shimamura $\mathrm{M}$, et al. Etiological correlation of human papillomavirus infection in the development of female bladder tumor. APMIS. 2013;121(12):1169-76.

21. Berrada N, Al-Bouzidi A, Ameur A, Abbar M, El-Mzibri M, Ameziane-ElHassani R, et al. Human papillomavirus detection in Moroccan patients with bladder cancer. J Infect Dev Countries. 2013;7(08):586-92.

22. Alexander RE, Williamson SR, Richey J, Lopez-Beltran A, Montironi R, Davidson DD, et al. The expression patterns of p53 and p16 and an analysis of a possible role of HPV in primary adenocarcinoma of the urinary bladder. PLOS ONE. 2014;9(4):e95724.

23. Borkowska EM, Kruk A, Jedrzejczyk A, Rozniecki M, Jablonowski Z, Traczyk $M$, et al. Molecular subtyping of bladder cancer using K ohonen selforganizing maps. Cancer Med. 2014;3(5):1225-34.

24. Golovina D, Trofimova O, Ermilova V, Matveev V, Volgareva G. Complex of molecular genetic and immunohistochemical methods for detection of human papillomavirus in the bladder cancer epithelium. Bull Exp Biol Med. 2014;157(1):70-3.

25. Kim SH, Joung JY, Chung J, Park WS, Lee KH, Seo HK. Detection of human papillomavirus infection and p16 immunohistochemistry expression in bladder cancer with squamous differentiation. PLoS ONE. 2014;9(3):e93525.

26. Pichler R, Borena W, Schäfer G, Manzl C, Culig Z, List S, et al. Low prevalence of HPV detection and genotyping in non-muscle invasive bladder cancer using single-step PCR followed by reverse line blot. World J Urol. 2015;33(12):2145-51.

27. Schmid SC, Thümer L, Schuster T, Horn T, Kurtz F, Slotta-Huspenina J, et al. Human papilloma virus is not detectable in samples of urothelial bladder cancer in a central European population: a prospective translational study. Infect Agents Cancer. 2015;10(1):1-6.

28. Anwar M, Khaleel M, Bukhari M, Imam S. Detection of human papilloma virus from urinary bladder carcinoma. Biomedica. 2015;31(2):66.

29. Golovina D, Ermilova V, Zavalishina L, Andreeva YY, Matveev V, Frank G, et al. Loss of cell differentiation in HPV-associated bladder cancer. Bull Exp Biol Med. 2016;161(1):96-8.

30. Jørgensen KR, Høyer S, Jakobsen JK, Jensen TK, Marcussen N, Wrist Lam G, et al. Human papillomavirus and squamous cell carcinoma of the urinary bladder: DaBlaCa-10 study. Scand J Urol. 2018;52(5-6):371-6.

31. Llewellyn MA, Gordon NS, Abbotts B, James ND, Zeegers MP, Cheng K, et al. Defining the frequency of human papillomavirus and polyomavirus infection in urothelial bladder tumours. Sci Rep. 2018;8(1):1-6.

32. Mete UK, Shenvi S, Singh MP, Chakraborti A, Kakkar N, Ratho RK, et al. Human papillomavirus in urothelial carcinoma of bladder: an Indian study. Int J Appl Basic Med Res. 2018;8(4):217.

33. Abdollahzadeh P, Madani SH, Khazaei S, Sajadimajd S, Izadi B, Najafi F. Association between human papillomavirus and transitional cell carcinoma of the bladder. Urol J. 2017;14(6):5047-50.

34. Javanmard B, Barghi MR, Amani D, Karkan MF, Mazloomfard MM. Human papilloma virus DNA in tumor tissue and urine in different stage of bladder cancer. Urol J. 2019;16(4):352-6.

35. Sarier M, Sepin N, Keles Y, Imir L, Emek M, Demir M, et al. Is there any association between Urothelial carcinoma of the bladder and human papillomavirus? A case-control study. Urol Int. 2020;104(1-2):81-6.

36. Collins K, Hwang M, Hamza A, Rao P. Prevalence of high-risk human papillomavirus in primary squamous cell carcinoma of urinary bladder. Pathol-Res Pract. 2020:216(9):153084.

37. Gordetsky J, Spieker AJ, Pena MdCR, Kamanda S, Anderson MR, Cheville $J$, et al. Squamous cell carcinoma of the bladder is not associated with high-risk HPV. Urology. 2020;144:158-63.

38. Ohadian Moghadam S, Mansori K, Nowroozi MR, Afshar D, Abbasi B, Nowroozi A. Association of human papilloma virus (HPV) infection with oncological outcomes in urothelial bladder cancer. Infect Agents Cancer. 2020;15(1):1-8 
39. Yan $Y$, Zhang H, Jiang C, Ma X, Zhou X, Tian X, et al. Human papillomavirus prevalence and integration status in tissue samples of bladder cancer in the chinese population. J Infect Dis. 2021;224(1):114-22.

40. Yıldızhan M, Koçak I, Kırdar S, Çulhacı N. Detection of human papillomavirus using polymerase chain reaction methods in transitional urothelial bladder cancer.

41. Eslami G, Golshani M, Rakhshon M, Fallah F, Goudarzi H. The study on relation of Human Papillomavirus with bladder transitional cell carcinoma. Cancer Ther. 2008;6:355-60.

42. Zhang Y. Understanding the gender disparity in bladder cancer risk: the impact of sex hormones and liver on bladder susceptibility to carcinogens. J Environ Sci Health C. 2013;31(4):287-304.

43. Shaker OG, Hammam OA, Wishahi MM. Is there a correlation between HPV and urinary bladder carcinoma? Biomed Pharmacother. 2013;67(3):183-91.

44. Li N, Yang L, Zhang Y, Zhao P, Zheng T, Dai M. Human papillomavirus infection and bladder cancer risk: a meta-analysis. J Infect Dis. 2011;204(2):217-23.

45. Selma WB, Ziadi S, Gacem RB, Amara K, Ksiaa F, Hachana M, et al. Investigation of human papillomavirus in bladder cancer in a series of Tunisian patients. Pathol Res Pract. 2010;206(11):740-3.

46. Walboomers JM, Jacobs MV, Manos MM, Bosch FX, Kummer JA, Shah $\mathrm{KV}$, et al. Human papillomavirus is a necessary cause of invasive cervical cancer worldwide. J Pathol. 1999;189(1):12-9.

47. Chang F, Lipponen P, Tervahauta A, Syrjäne S, Syrjänen K. Transitional cell carcinoma of the bladder: failure to demonstrate human papillomavirus deoxyribonucleic acid by in situ hybridization and polymerase chain reaction. J Urol. 1994;152(5):1429-33.

48. Alexander RE, Hu Y, Kum JB, Montironi R, Lopez-Beltran A, MacLennan GT, et al. p16 expression is not associated with human papillomavirus in urinary bladder squamous cell carcinoma. Mod Pathol. 2012;25(11):1526-33.

49. Youshya S, Purdie K, Breuer J, Proby C, Sheaf M, Oliver R, et al. Does human papillomavirus play a role in the development of bladder transitional cell carcinoma? A comparison of PCR and immunohistochemical analysis. J Clin Pathol. 2005;58(2):207-10.

50. Yavuzer D, Karadayi N, Salepci T, Baloglu H, Bilici A, Sakirahmet D. Role of human papillomavirus in the development of urothelial carcinoma. Med Oncol. 2011;28(3):919-23.

51. Alexander RE, Wang L, Lopez-Beltran A, Emerson RE, Montironi R, Pedrosa $J A$, et al. Human papillomavirus (HPV)-induced neoplasia in the urinary bladder: a missing link? 2016.

52. Knowles M. Human papillomavirus sequences are not detectable by Southern blotting or general primer-mediated polymerase chain reaction in transitional cell tumours of the bladder. Urol Res. 1992;20(4):297-301.

53. Westenend P, Stoop J, Hendriks J. Human papillomaviruses 6/11, 16/18 and $31 / 33 / 51$ are not associated with squamous cell carcinoma of the urinary bladder. BJU Int. 2001;88(3):198-201.

54. Guo CC, Gomez E, Tamboli P, Bondaruk JE, Kamat A, Bassett R, et al. Squamous cell carcinoma of the urinary bladder: a clinicopathologic and immunohistochemical study of 16 cases. Hum Pathol. 2009;40(10):1448-52.

55. Blochin EB, Park KJ, Tickoo SK, Reuter VE, Al-Ahmadie H. Urothelial carcinoma with prominent squamous differentiation in the setting of neurogenic bladder: role of human papillomavirus infection. Mod Pathol. 2012;25(11):1534-42.

\section{Publisher's Note}

Springer Nature remains neutral with regard to jurisdictional claims in published maps and institutional affiliations. 